\title{
LITERATURE ON THE PERIPHERY OF CAPITALISM: BRAZILIAN THEORY, CANADIAN CULTURE ${ }^{1}$
}

\author{
Imre Szeman \\ McMaster University \\ Empire and culture have to be on the globalization agenda, especially in a \\ white invader-setter colony like Canada where... culture is supposed still \\ by too many to be something imported for consumption as an additive to, \\ or sedative for, economic servitude. \\ — Len Findlay, "Content Providers!" \\ The age of globalization is the age of universal contagion. \\ - Michael Hardt and Antonio Negri, Empire (136)
}

\section{Postcolonial Solidarities}

Any attempt to theorize the surprising similarities between Brazilian and Canadian cultural and literary history has to begin by openly acknowledging the vast and irrecoverable differences between them-differences of history, culture, economics, geography, and so on. Indeed, there seem to be so many differences that one might be inclined to see the points of connection as mere coincidence: the cultural circumstances and expressions of both countries might appear similar in outward appearance (or at least, might seem so in many cases), but their inner logic emerges out of entirely different material circumstances that cannot be passed over in silence. For instance, the forms and issues

\begin{tabular}{|l|l|l|l|l|}
\hline Ilha do Desterro & Florianópolis & $n^{\circ} 45$ & p.135-152 & jul./dez. 2003 \\
\hline
\end{tabular}


of Canadian postmodern or postcolonial fiction bear some resemblance to magical realism or to Brazilian fictional expressions of the dilemmas of postcolonial cultural autonomy. Nevertheless, only the most retrograde form of comparative literature would feel comfortable assigning these forms the same meaning, the same social value, or the same social or cultural role and significance.

This does not, it seems to me, mean that there is no value in making connections or comparisons between Brazil and Canada, and especially of doing so under the general rubric of postcolonial criticism and theory, which brings to the fore the historical and economic circumstances under which each nation came into existence. I would argue that such comparison is especially important for understanding Canadian culture and literature, over which there has been a long struggle for selfunderstanding. I want to suggest all too briefly here that because Canada has imagined itself as part of the mainstream of Western modernity instead of as a colonial society with its own unique form or mode of modernity - that is, because it has imagined itself as more like the United States or the United Kingdom than Brazil or Mexico (though what is the Liberal Party but a Canadian version of the PRI?) - it has misunderstood or never adequately explored the conditions of possibility of Canadian culture and literature. In order to make such connections, however, it seems to me that one would first have to have a different sense of the postcolonial than the form that this concept or practice generally takes in the academy today. Though the concept of the postcolonial is notoriously flexible, applicable to an increasingly wide range of sites and situations, from the writing and culture of minority communities within Western countries to the literatures of the former Soviet Bloc countries, it is the general ethos of the postcolonial that needs to be refigured rather than the geographic regions to which one might consider safely applying it.

In contrast to the underlying universalistic assumptions of comparative literature (which have all but been dissolved in its transformation, in North America at least, from the study of literature to 
the study of theory), one of the main lessons of postcolonial criticism has been "that postcolonial societies, cultural formations and movements emerge at different times, in different forms and in different places around the globe" (Moore-Gilbert 203). These differences need to be attended to: even if Canada can be considered, as Peter Worsely suggests, "the world's richest underdeveloped country" (22), its modernity is not that of Brazil's, nor is it 'postcolonial' in the same way as even the other outposts of British colonialism in the Western hemisphere. Such apparent lack of attention to defining differences is no doubt part of the reason why Fredric Jameson's proposal that postcolonial literature be read as "national allegory" was greeted with such hostility: totalizing gestures of this kind could not but be read as in opposition to the very ethos of postcolonial criticism. ${ }^{2}$ Yet even though this attention to difference (to the difference of differences) has formed the dominant vision of the project of postcolonial studies, it is still only one version of the postcolonial, underwritten by its own (largely unacknowledged) grand theories concerning the nature of subjectivity and agency that express the common-sense of the Western's academy understanding of the connection between individual volition and the possibility of politics per se. While it has been supremely attentive to difference, postcolonial studies has often been hazy about continuities and structural similarities of the kind that comparative analyses probe and attempt to highlight. Jameson might have been wrong about the specifics of his analyses of third-world texts, but the attempt to relate the postcolonial situation to material circumstances that are necessarily global (i.e., imperial capitalism) seems theoretically unimpeachable and more necessary now than ever.

One form of comparison pushes towards violence and the leveling of differences, both theoretically and empirically; another, which is what Samir Amin describes as "genuine universalism," articulates the activity fundamental to the construction of the solidarities out of which politics grows. Many writers have written recently of a "crisis" in 
postcolonial criticism that has emerged out of its recent institutional acceptance (Seshadri-Crooks) and its encounter with a new set of historical circumstances and relations that have come to be referred to as "globalization." For some postcolonial critics, globalization is just more of the same old imperialism, but through different means (the spread of consumerism and mass culture) and through a new, singular historical agent: the United States (Ashcroft 112-3). For others, globalization has refigured the empirical and theoretical landscape so significantly that is demands new theoretical models to understand the dynamism of contemporary capitalism and its exercise of hegemony along multiple vectors (Appadurai). If globalization names a situation of crisis for postcolonial thought, it seems to me that it is because the postcolonial can no longer adequately theorize the contemporary circulation of power, or understand the dynamism of a capitalism that exercises hegemony by cultivating difference rather than seeking to contain or obliterate it (Dirlik, Miyoshi). No one objects to difference today; indeed, biopolitical power circulates by means of it. As Michael Hardt and Antonio Negri write, theorists "who advocate a politics of difference, fluidity and hybridity in order to challenge the binaries and essentialism of modern sovereignty have been outflanked by strategies of power" (138). Which should not be taken as a signal of the end of postcolonial criticism, as Hardt and Negri seem to suggest, but as an impetus to rediscover or invent a new theoretical framework that would permit one to think the underlying logic by and through which the periphery is produced as periphery, while also being attentive to the multiple modernities produced by global capitalism.

Even for those critics who have been wary of its rhetoric, globalization has occasioned a furious pursuit of new theories and models of a social reality imagined as fundamentally transformed. In the case of postcolonial studies, although a theoretical encounter with globalization is long overdue (see $\mathrm{O}^{\prime}$ Brien and Szeman), it seems to me that it is by means of a rediscovery of an earlier form of postcolonial thought that a more politically and theoretically productive way of 
thinking about the globe's multiple modernities might emerge. This is especially true of attempts to think about these modernities in relation to one another, and to think their relationships whether or not they are the product of the same colonial power (the organizing logic of most postcolonial criticism to date). As Bart Moore-Gilbert points out, one of the reasons for the recent sense of crisis in postcolonial criticism emerges out of its constitutive split character. Its main fault line or point of rupture lies in the discontinuities between the criticism of figures such as Chinua Achebe, Wole Soyinka and Wilson Harris, and that of Edward Said, Gayatri Spivak, and Homi Bhabha-between, that is, the attempt to highlight the complementarity of different postcolonial formations and develop global solidarities, and the emphasis on the politics of heterogeneity and difference. Even if we want to avoid returning to universalistic narratives, whether or not they are now (supposedly) purged of their Eurocentrism (as in some discourses of cosmopolitanism), it seems to me that globalization prompts us to seek out global complementaries and solidarities (of the kind, for instance, tentatively put forward by the Group of 77 during the high point of postcolonial state politics.) Only a postcolonialism that attends to continuities and similarities can work actively against the dominant narrative of globalization as global neoliberalism, by activating other narratives of globalization that are currently hindered by an insistence of the irreducible particularity of local circumstances. The following brief foray into the lessons that Canadian culture can learn from Brazilian theory is written with this framework in mind.

\section{Misplaced Ideas: From Brazil to Canada}

I have wanted to write for some time about the shock of recognition that greeted me when I first read through Roberto Schwarz's Misplaced Ideas: Essays on Brazilian Culture. Schwarz's main concern is to examine the central intellectual and theoretical problems that arise inevitably in the analysis of the culture of Brazil. What surprised me was how similar these problems were to those found in attempts to 
theorize the conditions of Canadian culture and, be extension, Canadian literature. From what I've said thus far, it should be clear that this is not to suggest that the correlation is exact-that is, that there is a precise structural homology between Brazil and Canada that will tell us everything that we ever wanted to know about Canadian culture and writing now and in the future. Nevertheless, the similarities are striking enough that they are worth examining, especially since it seems to me that indirectly approaching some old issues in Canadian literature reveals some unexpected blind spots that still require critical illumination.

While Schwarz shows that there are any number of "misplaced ideas" in relation to Brazilian culture, an important set of these circulates around a problem intimately familiar to an earlier generation of Canadian writers: the way in which Brazilian and Latin American culture has always been experienced as "artificial, inauthentic and imitative" (1). Schwarz suggests that Brazilian culture has, for more than a century and from competing points of view (right, left, modernist, nationalist, cosmopolitan, etc.), been seen as derivative-as existing in relation to the West in the same way that a copy relates to an original. In line with the work of other postcolonial writers and critics, Schwarz draws attention to the belief that one's culture is somehow inauthentic or derivative as ideological in the most common sense of the term: a false structure of belief passed off as reality in order to suppress an understanding of the true nature of social and political power. What is suppressed in this idea of cultural inauthenticity, in Canada as much as in Brazil, is a recognition of the material, historical circumstances that first established the idea of an "original" culture to which others, by contrast, seem to be mere copies. The root cause in both cases can be found it the long process of European imperialism and the array of ideologies and concepts associated with it that served to enable, legitimate, and sustain the imperial project: discourses related to its religious and civilizing mission, the discourse of anthropology and its concern with the primitive, Eurocentric discourses of modernization 
and development, and even the teleological claims of Marxism and its assertions about the inevitability of certain stages of historical development (as in the infamous Asiatic mode of production). As Schwarz shows in the case of Brazil, believing that one's culture is merely a pale imitation of a more fully and more genuinely realized one produces a social and cultural malaise that seems to be impossible to throw off. This is a feeling that Canadians are well aware of, and, at least in part, it is the attempt to break free of this malaise that has fuelled a great deal of Canadian writing throughout its history.

If a sense of cultural inauthenticity is ideological in the sense that it constitutes a false belief, then it seems that the solution is simple enough: recognizing the reality behind the illusion should be enough to shatter it and set us free. Besides the fact that this is an entirely idealist solution to a materialist problem, Schwarz explains why it hasn't been that easy to locate a solution. Once in place, the focus on inauthenticity as the origin of social and cultural problems generates a cultural dialectic that never adequately resolves itself in order to produce the desired end: a genuine national culture. "Nothing seems more reasonable, for those who are aware of the damage," Schwarz writes, "than to steer in the opposite direction and think it is enough to avoid copying metropolitan trends in order to achieve an intellectual life with great substance" (3). The desire to reject everything foreign, to isolate and destroy the bacteria that have invaded the national host in order to leave it pure and free of disease, was the motivating idea behind Brazilian cultural and economic nationalism in the 1960s, just as it was in Canada during the same period. Not surprisingly, in neither case was nationalism successful in eliminating the contagion of the foreign and leaving behind a healthy body that could be identified as purely Brazilian or Canadian: from the beginning, the opposition between the national and the foreign at work in cultural nationalism was an unreal one that did "not allow us to see the share of the foreign in the nationally specific, or the imitative in the original and of the original in the imitative" (16). On the other side of this dialectic, rejecting nationalism 
while embracing what might be seen as a more cosmopolitan perspective is equally problematic. Giving up on the idea that there can be an authentic national culture by treating this idea as "a provincial phenomenon associated with archaic forms of oppression" seems to represent a step forward (5). At the same time, as Schwarz points out, given the context of the international mass media against which these suggestions were framed in the period after the 1960s, "an emphasis on the international dimension of culture becomes no more than a legitimation of the existing mass media," and this is not "emancipatory or aesthetically acceptable" (5). If these two positions mark out the territory of possible solutions to the crisis of an inauthentic culture, then there doesn't appear to be much hope that Brazil can overcome the sense that it possesses a derivative culture; neither solution is adequate, and in fact each generates new problems of authenticity, whether in the form of a mythologized, exclusionary nationalism developed in opposition to the taint of the foreign or in the form of a false cosmopolitanism that represents little more than a belated acceptance of the global order and Brazil's place within it.

It seems to me that at the core of the problem that Schwarz identifies in Brazilian culture-at the heart of what permits this arrested dialectic of inauthenticity to circulate endlessly-is a sense of belatedness, of having arrived too late on the historical scene, at the end of a Western modernity that had completely mapped out the landscape in advance. The points of overlap between the project of national culture in Brazil and Canada emerge fully when considered in relation to this temporal figure. The sense of belatedness has been central to the problem of Canadian culture and literature. For example, it makes an appearance at an important juncture in Northrop Frye's conclusion to the first edition of the Literary History of Canada: Canadian Literature in English. What is finally posed famously as a spatial question-"Where is here?"emerges from a consideration of the unique temporal problem faced by Canadian literature and culture: 
English Canada was first a part of the wilderness, then a part of North America and the British Empire, then a part of the world. But it has gone through these revolutions too quickly for a tradition of writing to be founded on any one of them. Canadian writers are, even now, still trying to assimilate a Canadian environment at a time when new techniques of communication, many of which, like television, constitute a verbal market, are annihilating the boundaries of that environment. (826)

For Frye, Canadian writing comes into the world too late for it to be organically distinctive or authentically representative of the national space in which it originates. Canadian writing is belated because the world in moving too fast for it to assimilate both its successive phases of development (which arrive and speed by without any internal, national compulsion) and now, decisively, the new technological environments being produced transnationally. The net effect of what we would now describe as globalization is to annihilate what, in the preface to The Bush Garden, Frye identifies as "the sense of a specific environment as something that provides a circumference for an imagination" (iii). In other words, even if Canadian writing were somehow able to "catch up" so that it would no longer experience this sense of belatedness, it would then find that the conditions for cultural specificity—that is, for a truly national literature-have been thoroughly eclipsed. The two solutions to the problem of cultural inauthenticity outlined by Schwarz are more or less reproduced in Frye's consideration of Canadian writing. Here, too, there seems to be no way forward, since it is neither possible to assert a real national distinctiveness nor to claim unproblematic assent to a global cultural playing field whose rules were established outside Canada.

In Frye's case, however, a different possibility emerges from his consideration of the significance of mass communication and mass media on Canadian culture and writing. (Incidentally, almost four decades later these concerns, more pressing than ever, are dealt with 
infrequently by Canadian literary critics and writers.) With respect to Frye, Richard Cavell has argued in his examination of what he describes as the "Frye-McLuhan debate" that, by the 1970s, Frye was no longer defending the virtues and verities of literary culture and its inherently civilizing qualities. Influenced by McLuhan's ideas on the function of contemporary media and on Canada's position as a "borderline" country-borderline not merely because Canada was poised between the foreign and the national, the cosmopolitan and the bust, but also because it was beyond these dichotomies-by 1980 Frye saw as a solution to the problem of belatedness what he had once seen as a threat to Canadian literature. "In an 'instant' world of communication," he writes, "there is no reason for cultural lag or for a difference between sophisticated writers in large centers and naive writers in smaller ones. A world like ours produces a single international style of which all existing literatures are regional developments" (qtd. in Cavell 262). In this way, the global modernity that once consigned belated nations like Brazil and Canada to the cultural periphery offered a technological solution to the historical-metaphysical problem of cultural inauthenticity. We should remember that the relationship of the original to the copy is also a temporal one: the copy is deficient not merely or even primarily because it reproduces all of the features of the original, but because it comes after it in time. If the problem of cultural inauthenticity is understood as a temporal problem, then a solution to cultural belatedness and its consequent cultural malaise might be to flatten time. The ideological order to succession of cultures (primary, secondary, tertiary, etc.) is thus dismantled. In effect, this is what Frye claimed on behalf of McLuhan: the problem of Canadian belatedness is resolved once and for all by the creation of a single global time in which it is no longer possible to position oneself as out of sync with the main currents of modernity. ${ }^{3}$

Frye's solution to the problem of Canadian cultural specificity has been largely accepted by contemporary Canadian writers and critics, and indeed, by Brazilian writers, too: we are all cosmopolitans now. Hardly imagining itself any longer as inauthentic or as secondary to 
more established literatures, Canadian writing is now spectacularly self-confident and globally respected. Yet for all of the welcome success of contemporary Canadian writing, something should trouble us about Frye's embrace of the instantaneous present and the international style as a joint solution to the problem of Canadian culture. As Cavell points out, Frye's evocation of the "international style" in The Modern Century was "made in the service of his larger theory that the forms of literature are autonomous: given, however, that these 'autonomous' forms are those of classical European literature, they simply resurrect [A.J.M.] Smith's distinction between naive and cosmopolitan" (256). It is not clear whether, a decade or so later, his evocation of an international style is any less Eurocentric in its claims or in its suggestion that we are all cosmopolitans now because, having never been properly established, not even a residue of the provincial voice has been left behind.

It seems to me that what has been substituted in this vision of "a single international style of which all existing literatures are regional developments" is merely one ideology about time and culture for another. What I have been describing as belatedness Paul Smith, drawing on the work of Johannes Fabian, has described as the denial of "allochronism": the denial to the "Other" of a contemporaneity with the West, which means that the Other may then be seen as primitive, underdeveloped, and uncivilized and therefore in need of intervention by the West in order to make it modern, developed, and civilized (12). With this, Smith contrasts the new rhetoric and ideology of contemporary global capitalism. Globalization has been represented repeatedly in both popular and academic writing through a series of by now familiar images: that of a "fully global space replete with an ecstatic buzz of cyber communications, or of an instantaneous mobility of people, goods, and services, or of a global market place hooked up by immaterial money that flashes around the globe many times a minute" (13). Smith insists that these images of globalization do not represent the reality of the global present. Rather, they constitute a concerted attempt to conjure away the contradictions created by an intensified neoliberal capitalism than has in fact deepened the divide between the North and the South, 
the West and the rest. It does so by projecting an image of the world that is isochronic, a world in which everything happens at the same time and thus one in which the problems and contradictions produced by an earlier, imperialist capitalism are done away with just as surely as are the limitations of time and space. This rhetoric has become so thoroughly embraced by even many progressive political and social groups around the world, who have come to see globalization as inevitable and largely unalterable, that is has become hard to believe what everyone nevertheless senses: far from changing anything, this isochronic dream of capitalism is merely a way of "denying allochronism to the other in a new way" (13).

What is missing in Frye's assessment of the fate of Canadian writing, just as surely as in the collective Canadian joy over the vigour of its contemporary writing on the global stage, is a level of analysis that might get us beyond the dilemma of cultural identity outlined by Schwarz. Instead of replacing a lamentable belatedness with a problematic acquiescence to global capitalism's isochronic dream, we need to dig deeper to find the root cause of the inauthenticity felt in both Brazil and Canada if we want to understand the direction of Canadian literature in the new millennium. Schwarz concludes that "the painfulness of an imitative civilization is produced not by imitation-which is present in any event—but by the social structure of the country" (15). Put more bluntly, "it is not copying in general but the copying of one class that constitutes the problem" (11). It is perhaps easier to see this in the case of Brazil than that of Canada, largely because of the more extreme social hierarchies produced by the institution of slavery and the latifundia. The parallels between the two colonial situations should nevertheless prompt us to see Canadian writing in a different way. Schwarz notes that in Brazil, before the nineteenth century, the imitation of Europe by the ruling class did not constitute a problem. Far from it: its estrangement from the masses and its close connection to the culture of the "home country" were two of the chief sources of its legitimacy as the class in power. It was independence- 
which, just as in Canada, did not involve a revolution-that created a new set of political relations that consequently has an effect on Brazilian culture. Independence left the ruling hierarchy largely in place, even as it introduced "modern" forms of citizenship, ideas of freedom, and concepts of political emancipation. The ruling hierarchy thus faced a dilemma: "deprecating the bases of its social pre-eminence in the name of progress, or deprecating progress in the name of its social preeminence" (12). The drama of cultural inauthenticity arose out of this dilemma. As the modern, progressive forces of an expanded democracy came to the fore over time, it became increasingly difficult to assert the authenticity of the old, happily imitative, colonial order in Brazil against the new conditions of citizenship. At the same time, in order to maintain political power, the indigenous ruling class had to assert a cultural difference from the masses, who in Brazil-just as in Canada-have never been troubled by the idea that their culture doesn't quite measure up to some outside standard. Brazil's unhappily imitative national culture-or at least the culture that claims to represent the nationarose as a longing for an earlier, less problematic, class hierarchy in a new world situation in which it became necessary to produce a culture ex nihilo: a new culture, neither working-class nor colonial, but something else. But this culture, such as it is, has always lacked the material conditions to sustain it beyond its always hesitant, uncertain ideological function as the ready-to-hand discourse to explain the dissatisfactions of life on the periphery.

When we accept global capitalism's isochronic rhetoric to lend support to the current success of Canadian writing, we are in effect burying ever deeper the structural conditions that produced our earlier feelings of cultural inauthenticity. We do likewise when we take the current success of Canadian literature as evidence of a kind of Canadian exemplarity with respect to the modern (as articulated by McLuhan) or postmodern (as per Linda Hutcheon) that has permitted Canadian culture to be a hothouse for global culture avant la lettre. In both cases, we suppress our ability to ask deep questions about the political and 
social function of Canadian literature with respect to everyday life in Canada, especially as expressed in class terms. In opposition to this isochronic ideology, I think that it is worth retaining the idea that Canadian culture is a belated (i.e., postcolonial) culture in order to remind ourselves of the social and political bases of our sense of what culture is and how we imagine its relationship to the production of the nation. Diana Brydon has suggested that "withholding the status of 'authentic' colonialism from countries such as Canada... makes it harder for all Canadians to identify and combat the particular kinds of postcolonial experience they are currently undergoing as they watch their economy shrink, jobs disappear, and cultural sovereignty erode" (11). It is equally the case that failing to understand the political and social function of Canadian literature as it relates to class makes it difficult to understand the ways in which Canada is more like Brazil than we might have imagined.

\section{Volubility and Ressentiment}

A brief word on literary history by way of conclusion. Just as his Misplaced Ideas helps us to see absences and gaps in disputes over Canadian culture, which remain firmly in place in recent debates over cultural policy in Canada and the impact of a global mass culture that is always read in Canada as "American," the recent translation of $A$ Master on the Periphery of Capitalism, Schwarz's majestral analysis of Machado de Assis' The Posthumous Memoirs of Brás Cubas, offers a model for re-thinking Canadian literary history in terms of class. Schwarz's elaborate analysis highlights the connections between social and literary form in Machado's most famous novel. Refusing to read the novel's stunning and unprecedented fragmentary form as a sign of Brazilian cultural maturity (as postmodernism avant la lettre), Schwarz explains the way in which the "volubility" (volubilidade) of Machado's novel, its endless and startlingly shifts of tone, sentiment, opinion, form, and style "retain the specific features... of a motion or course imposed on the Brazilian ruling class by historical circumstances-or, if one 
prefers, that those circumstances allowed it to have" (20). I've already offered some sense of what Schwarz (and Antonio Candido before him) took these circumstances to be. Brás Cubas exemplifies that problem of 'misplaced ideas' in a nutshell (it is, of course, an analysis of Machado's fiction that allowed Schwarz to derive this concept in the first place). He writes:

A vital part of the volubility... is the accelerated and perfunctory consumption of attitudes, ideas, convictions, literary manners, and more, soon abandoned for others and thus discredited. This movement has recourse to the stock of enlightened appearances, and in this way, when it is taken to its final consequences, mocks the totality of contemporary thinking, which is subordinated to a principle contrary to it and thus deprived of credibility. This is the course or trajectory that history allowed, or imposed upon, the Brazilian ruling class as a whole. (23)

In order to understand nineteenth and twentieth-century literary production in Canada, a similar mapping of the connections between literary form and social conditions is essential. I am not suggesting that this hasn't been done; however, imagining Canada as Brazil prompts a different view of nineteenth-century social relations, and thus of literary production as well. Canadian modernity, too, is constituted along a rift between Enlightenment progress, in the form of emancipation and the extension of civil liberties on one hand, and a mode of production that in a country of "hewers of wood and drawers of water" has relied on a domestic and immigrant labour force that has rarely (and certainly not in the present era of globalization) been able to access the freedoms formally guaranteed them. The plight of worker's and of immigrant communities has of course been the subject of numerous Canadian novels, from the accounts of early settler's to the immigrants in John Marilyn's Under the Ribs of Death, and from Michael Ondaatje's In the Skin of a Lion to the enormous body of exceptional novels released 
over the past decade by South East Asian and Caribbean-Canadian writers. But it is only recently that a common, defining formal principle has been identified in Canadian writing. In his analysis of a number of nineteenth-century Canadian texts, including Charles Mair's historical drama Tecumseh and James DeMille's A Strange Manuscript Found in a Copper Cylinder (like Brás Cubas, a text often taken as voicing a postmodern-like critique of interpretation), Glenn Willmott identifies a form of literary ressentiment particular to Canadian texts. Willmott appeals to the meaning Friedrich Nietzsche gives to the concept of ressentiment in On the Genealogy of Morals. It is

the fiction of moral superiority and myth of apocalyptic vindication which are invented by the weak as a reaction and constitute their negative identity formation, against the strong. It is this negative double of an American dream, the monster of a Canadian ressentiment that we find... wherever we look for expressions of social purpose and unity in the literature of the formative period of Canadian nationalism, and whose persistence Canadians still feel today. (137)

What remains to be determined are the social and political circumstances that produced and continue to reproduce this ressentiment, which like Brás Cubas' volubility is related to the ambiguous, contradictory circumstances faced by the Canadian elite at the end of the nineteenth century, which has made it endlessly possible for both material and legal injustices to be excused as necessary part of the efforts of the United States' "postcolonial betters."

\section{Notes}

1. An earlier version of this paper appeared as "Belated or Isochronic? Canadian Writing, Time, and Globalization," Essays on Canadian Writing 71 (2000): 145-53. 
2. For a discussion of critical misreadings of Jameson's infamous essay on thirdworld literature, see my "Who's Afraid of National Allegory? Jameson, Literary Criticism, Globalization," South Atlantic Quarterly 100.3 (2002): 801-25.

3. See also Frye, Conclusion: "The writers of the past decade, at least, have begun to write in a world which is post-Canadian, as it is post-American, post-British, and post everything except the world itself. There are no provinces in the empire of the aeroplane and television, and no physical separation from the centres of culture, such as they are. Sensibility is no longer dependent on a specific environment or even on sense experience itself" (848).

\section{Works Cited}

Amin, Samir. Eurocentrism. Trans. Russell Moore. New York: Monthly Review P, 1989.

Appadurai, Arjun. Modernity at Large: Cultural Dimensions of Globalization. Minneapolis: U of Minnesota P, 1996.

Ashcroft, Bill, Gareth Griffiths and Helen Tiffin. Key Concepts in Postcolonial Studies. New York: Routledge, 1998.

Brydon, Diana. "Introduction: Reading Postcoloniality, Reading Canada." Essays on Canadian Writing 56 (1995): 1-19.

Cavell, Richard. "Material Querelle: The Case of Frye and McLuhan." Essays on Canadian Writing 68 (1999): 242-65.

Dirlik, Arif. The Postcolonial Aura. Boulder: Westview P, 1997.

Findlay, Len. "Content Providers of the World Unite! A Critical Canadian Analysis and Agenda." Topia 8 (2002), forthcoming.

Frye, Northrop. "Conclusion". Literary History of Canada: Canadian Literature in English. Ed. Carl F. Klinck. Toronto: U of Toronto P, 1965. 821-49

Preface. The Bush Garden: Essays on the Canadian Imagination. Toronto: Anansi, 1971.

Hardt, Michael, and Antonio Negri. Empire. Cambridge: Harvard UP, 2000. 
Jameson, Fredric. "Third-World Literature in the Era of Multinational Capitalism." Social Text 15 (1986): 65-88.

Miyoshi, Masao. "Turn to the Planet: Literature, Diversity, and Totality." Comparative Literature 53.4 (2001): 283-97.

Moore-Gilbert, Bart. Postcolonial Theory: Contexts, Practices, Politics. New York: Verso, 1997.

O'Brien, Susie, and Imre Szeman, eds. Anglophone Literatures and Global Culture. Spec. issue of South Atlantic Quarterly 100.3 (2001).

Schwarz, Roberto. A Master of the Periphery of Capitalism. Trans. John Gledson. Durham, NC: Duke UP, 2001.

Misplaced Ideas: Essays on Brazilian Culture. Ed. John Gledson. New York: Verso, 1992.

Seshadri-Crooks, Kalpana. "At the Margins of Postcolonial Studies: Part 1." In The Pre-Occupation of Postcolonial Studies. Ed. Fawzia Afzal-Khan and Kalpana Seshadri-Crooks. Durham, NC: Duke UP, 2000. 3-23.

Smith, Paul. Millennial Dreams: Contemporary Culture and Capital in the North. New York: Verso, 1997.

Willmott, Glenn. “Canadian Ressentiment." New Literary History32.1 (2001): 133-56.

Worsely, Peter. The Three Worlds: Culture and World Development. Chicago: U of Chicago P, 1984. 